\title{
Ameliorating effects of curcumin and propolis against the reproductive toxicity of gentamicin in adult male guinea pigs: Quantitative analysis and morphological study
}

\author{
Fathy Ahmed Fetouh ${ }^{1}$, Azab El Saied Azab ${ }^{2}$ \\ ${ }^{1}$ Department of Anatomy, Faculty of Medicine, Zagazig University, Egypt \\ ${ }^{2}$ Department of Zoology, Alegelat Faculty of Science, Zawia University, Libya
}

Email address:

Fghait@yahoo.com (F. A. Fetouh)

\section{To cite this article:}

Fathy Ahmed Fetouh, Azab El Saied Azab. Ameliorating Effects of Curcumin and Propolis against the Reproductive Toxicity of Gentamicin in Adult Male Guinea Pigs: Quantitative Analysis and Morphological Study. American Journal of Life Sciences.

Vol. 2, No. 3, 2014, pp. 138-149. doi: 10.11648/j.ajls.20140203.13

\begin{abstract}
Infertility is a growing worldwide problem and about half of the causes could be traced in male partner. Aim of the work: the present work aimed to study propolis and curcumin for their potential ameliorative effects on reproductive toxicity induced by gentamicin in guinea pigs from morphological and quantitative aspects. Materials and methods: 36 guinea pigs were used for this study and divided into 6 groups. The first 3 groups were control (normal control, curcumin administered, and propolis administered), the 4th group was the experimental and administered gentamicin at a dose of 5 $\mathrm{mg} / \mathrm{kg}$ body wt for 10 days, and in the 5 th and 6th groups, gentamicin was co-administered with propolis and curcumin at the doses of $50 \mathrm{mg}$, and $10 \mathrm{mg} / \mathrm{kg}$ body wt respectively. The animals were sacrificed and the testes were dissected out from which specimens were obtained. The specimens were processed for light microscopic examinations and quantitative analysis. Blood samples were obtained for assessment of plasma testosterone level. Results: Structurally, in gentamicin treated animals, the seminiferous tubules showed sloughing of the germinal epithelium into lumen where sperms were few. The basement membrane appeared thick, irregular and degenerated. Wide interstitial spaces with few Leydig cells were observed. From the quantitative aspect, the percent of volume density and absolute volume of seminiferous tubules were significantly reduced. Also, the diameter, total length, and total surface area of seminiferous tubules were significantly reduced. The numbers of Sertoli cells, round spermatids and daily sperm production per testis and per gram of testicular tissue were significantly decreased in gentamicin treated guinea pigs. As regard to endocrine part of the testis, the percent of volume density of Leydig cell nuclei, the total number of Leydig cells, and plasma testosterone level were significantly decreased in gentamicin treated guinea pigs. With co-administration of propolis and curcumin, the structure of seminiferous tubules improved and their lumens were full of bundles of sperms. Also, all the parameters of seminiferous tubules and total numbers of Sertoli cells, round spermatids, daily sperm production and Leydig cells were ameliorated significantly as compared to gentamicin treated animals. Also, the testosterone level was improved. Conclusion: It can be concluded that, the gentamicin even at therapeutic dose can have adverse impacts on male reproduction. Administration of propolis or curcumin can ameliorate these effects. So, the patients while treated by gentamicin should be advised to use one of them.
\end{abstract}

Keywords: Gentamicin, Reproductive Toxicity in Male, Propolis, Curcumin, Quantitative Analysis, Histology, Guinea Pigs

\section{Introduction}

Infertility is one of the major problems in life and is represented in 25 and $35 \%$ in men and women respectively [1]. The decline in male reproductive health and fertility for the past 30 years has been linked to environmental toxicants and xenobiotics [2]. This can have harmful effects on spermatogenesis, normal sperm production [3] and quality of semen produced [4].

Gentamicin is an aminoglycoside antibiotic derived from micomonospora purpurea and still constitutes the only effective therapeutic alternative against microorganisms; pseudomonas, proteus and serratia that are insensitive to other antibiotics $[5,6]$. Moreover, aminoglycosides are 
routinely used by urologists and fertility specialists to treat bacterial infections occurring in patients prior to in vitro fertilization or when a higher concentration of leucocytes are present in the semen of these patients [7, 8]. Gentamicin was known to reduce sperm count, motility, and viability which may be due to increasing free radical formation and lipid peroxidation by decreasing the antioxidant enzyme levels [4]. Free radical-induced oxidative damage to spermatozoa has recently gained attention for its role in increasing poor sperm function and infertility [9].

Natural antioxidants strengthen the endogenous antioxidants defenses and restore the optimal balance by neutralizing reactive species $[10,11]$. Curcumin as one of the naturally occurring dietary substances has been used since ancient times for promoting human health [12]. Curcumin is a major yellow pigment in rhizomes of curcuma longa linn which is used widely as a spice and coloring agent in several foods [12-14]. It represents a class of anti-inflammatory and antioxidant that is reported to be a potent inhibitor of reactive oxygen species (ROS) formation [13-15]. Also, propolis is resinous natural product collected from cracks in the bark of trees and leaf buds which are enriched with salivary enzymes of honey bees. It has more than 180 compounds including flavonoids, phenolic acids and its esters [16-18]. Melatonin and caffeic acid phenethyl ester are compounds of hony bee propolis, that were recently found to be potent free radical scavengers and antioxidants [19].

Most of literatures regarding the reproductive toxicity of gentamicin stressed on the biochemical impacts on semen analysis [4, 7, 20-22]. Literatures on the structural and histometrical changes are scarce. Also, to our knowledge, the antioxidants curcumin and propolis were not tested for their protective effects against gentamicin induced testicular oxidative stress. Guinea pig is one of the experimental models which is rarely used and its testicular morphometry is deficient. So, the present work aimed to study propolis and curcumin for their potential ameliorative effects on the reproductive toxicity induced by gentamicin in guinea pigs from morphological and quantitative aspects.

\section{Materials and Methods}

\subsection{Chemicals}

Gentamicin and curcumin were purchased from Sigma Chemical Co. (St. Louis, Mo, USA). Propolis was obtained from hony bee colonies in the Faculty of Agriculture, Zagazig University, Egypt. Aqueous propolis extract was prepared according to the method of El-khayat et al. [23]. Briefly, propolis was kept dry and freezed $\left(-40^{\circ} \mathrm{C}\right)$ until used. Propolis samples were mixed with distilled water, heated gently and filtered through Whatman no:1 filter paper. Propolis was freshly prepared and administered to animals orally by gavage. The gentamicin was given at a dose of $5 \mathrm{mg} / \mathrm{kg} \mathrm{b}$. wt once daily intraperitoneally for 10 days. The dose and duration of treatment was similar as in human and confirmed oxidative stress in testis $[4,22]$. The choice of doses of curcumin and propolis were based on the results of previous studies [24-27], where the antioxidant effects of these agents were confirmed. Curcumin was given orally at a dose of $10 \mathrm{mg} / \mathrm{kg} \mathrm{b}$. wt by gavage and propolis was given at a dose of $50 \mathrm{mg} / \mathrm{kg} \mathrm{b}$. wt orally by gavage once daily for 10 days.

\subsection{Animals}

36 sexually mature (about 6 months old) male guinea pigs (Cavia porcellus) weighting 480-530 gm were used for this study. The animals were obtained from animal house unit in the Faculty of Veterinary Medicine, Zagazig University, Egypt. The animals were housed in a room under standard conditions of ventilation, temperature $\left(25 \pm 2{ }^{\circ} \mathrm{C}\right)$, and humidity (60-70\%) and subjected to natural photoperiod of 12 hours light: dark cycle throughout the experimental period. The animals were provided with tape water ad libitum and fed with the standard commercial chow. The procedures were performed in accordance with the national Guide Lines for Ethical Conduct in the Care and Use of Animals.

\subsection{Experimental design}

After one week of acclimation, the animals were randomized and divided into 6 groups (6 guinea pigs for each) as follow:

Group 1 (control group): the animals received intraperitoneal injection of saline $(0.5 \mathrm{ml} /$ day for 10 days $)$.

Group 2 (curcumin only): the animals received curcumin (10 mg/kg b. wt /day) orally by gavage for 10 days.

Group 3 (propolis only): the animals received propolis (50 $\mathrm{mg} / \mathrm{kg} \mathrm{b}$. wt /day) orally by gavage for 10 days.

Group 4 (gentamicin treated group): the animals received intraperitoneal injection of gentamicin only $(5 \mathrm{mg} / \mathrm{kg} \mathrm{b}$. wt /day) for 10 days.

Group 5 (gentamicin/curcumin co-administered): the animals received intraperitoneal injection of gentamicin (5 $\mathrm{mg} / \mathrm{kg} \mathrm{b}$. wt /day) concurrently with curcumin $(10 \mathrm{mg} / \mathrm{kg} \mathrm{b}$. wt /day ) orally for 10 days.

Group 6 (gentamicin/ propolis co-administered): the animals received intraperitoneal injection of gentamicin (5 $\mathrm{mg} / \mathrm{kg} \mathrm{b}$. wt /day) concurrently with propolis $(50 \mathrm{mg} / \mathrm{kg} \mathrm{b}$. wt /day) orally for 10 days.

\subsection{Tissue collection and processing}

At end of the experimentation and 24 hours after last dose, the animals were sacrificed by injecting ketamine (intraperitoneal) under general anesthesia, then the testes were rapidly dissected out and trimmed from tunica vaginalis and epididymis. The testes were weighted using an electronic scale. One testis from each animal (right or left) chosen in an alternating basis was placed in Bouin's solution. After 30 minutes, the poles were removed to enhance penetration of the fixative, and the tissue was returned to the fixative for a total of 24 hours [28]. The fixed testis was cut into top, middle and bottom sections. Each portion was then histologically processed, dehydrated in a graded series of ethanol, immersed in xylol and embedded in paraffin wax 
[29]. Two serial section $(5 \mu \mathrm{m})$ were made from each portion, mounted onto gelatin - coated glass slides and dried overnight at $37^{\circ} \mathrm{C}$. Sections were stained with hematoxylin - eosin and stored at room temperature. It is assumed that, the structure and cellular components of the testes in all groups studied undergo shrinkage to the same degree since they were subjected to the same kind of treatment during processing. The relative reduction in volume densities of the components would therefore be the same.

\subsection{Quantitative analysis of tissue sections}

\subsubsection{Assessment of tubular tissue volume}

The volume density of seminiferous tubules (ST) was obtained by point counting [30]. 30 randomly selected transverse sections of seminiferous tubules per animal for the six groups were examined under a binocular light microscope (Zeiss) equipped with a bright field condenser with a $40 \mathrm{x}$ objective and $16 \mathrm{x}$ eye piece fitted with a square lattice containing 441 intersections (Fig. 1A). The number of intersections over ST was counted by movement of sections across the grid without overlap. Volume density $\left(V_{D}\right)$ of ST (volume of ST per unit volume of testicular tissue) was obtained by dividing the sum of points falling on ST by the total number of points over the tissue (441). The results expressed as a percentage of the testis volume (V\%), were obtained by multiplying the volume density of ST by 100 . The absolute volume $\left(\mathrm{V}_{\mathrm{A}}\right)$ of ST was then determined by multiplying the volume density of ST by total testis volume (volume of one testis). The testis weight was converted to testis volume by dividing it by specific gravity of the testicular parenchyma. Since specific gravity of the testis is approximately 1.0 [31], the volume of the testis in guinea pigs is nearly equal to its weight.

\subsubsection{Assessment of diameter, total length and total surface area of $S T$}

Diameters of 30 randomly selected transverse sections of ST per animal were measured across the minor axis of their cross sectioned profiles with an ocular micrometer [32, 33] (Fig. 1B). The total length (L) and surface area (S) of ST per unit volume of the testis were calculated by the standard equation:

$$
L=\frac{V_{A}}{3.1415 \times r^{2}}
$$

and $\mathrm{S}=2 \times 3.1415 \times \mathrm{r} \times \mathrm{L}$

where $\left(\mathrm{V}_{\mathrm{A}}\right)$ is the absolute tubular volume per unit volume of testicular tissue as measured by point counting and " $\mathrm{r}$ " is the mean radius as determined from the diameter of ST [32-34].

\subsubsection{Assessment of Sertoli cells and round spermatids counting}

In 30 randomly selected transverse sections of ST per animal, the numbers of Sertoli cells and round spermatid nuclei present within each tubular cross-section were determined by direct counts [35]. Because these crude counts contained both whole nuclei and fragments produced by sectioning, initial cell counts were corrected using Abercrombie's correction factor [36] as follow:

$$
\mathrm{n}=\text { cell count per tubular section } \times \frac{\sec \text { tion thickness }}{D+\sec \text { tion thickness }}
$$

where (D) is the mean diameter of Sertoli cell or round spermatid nuclei. The diameters of the nuclei were measured using an ocular micrometer and a x 100 oil immersion objective. The mean diameter (D) was obtained by measuring 10 nuclei per section per animal. Total number of Sertoli cells per testis was estimated by the equation:

$$
\text { Total n. of Sertoli cells }=\mathrm{n} \times \frac{L}{\sec \text { tion thickness }}
$$

where (n) is the mean corrected number of Sertoli cells per transverse section of ST, (L) is the total length of ST per testis [34]. The section thickness in the present study was 5 $\mu \mathrm{m}$. Also, the total $\mathrm{n}$. of round spermatids $=\mathrm{n}$ $\times \frac{L}{\text { sec tion thickness }}$

where (n) is the mean corrected number of round spermatids per transverse section of ST and (L) is the total length of ST per testis [34, 35, 37]. The number of cells per gram of testicular tissue was calculated by dividing the total number of Sertoli cells or round spermatids per testis by the weight of one testis.

\subsubsection{Assessment of daily sperm production}

Assessing the daily rate of sperm production by quantitative testicular histology based on that no significant loss of spermatids occurs during spermiogenesis [32, 38]. The time necessary to process the total number of spermatids in a testis (or gram of testis) would thus be the time period from stage I to stage $X$ of the cycle [32]. The total duration of spermatogenesis in guinea pigs is approximately 33.8 days [39]. As the time necessary for the cycle to proceed from stage $\mathrm{I}$ to stage $\mathrm{X}$ is $75.58 \%$ of the total cycle $[32,40]$. So, the time necessary for the cycle to proceed from stage $\mathrm{I}$ to stage $\mathrm{X}$ in guinea pigs is 25.54 days.

The daily sperm production in guinea pigs per testis $=$ $\frac{\text { Total n. of round spermatids per testis }}{25.54}$

The daily sperm production per gram of testis $=$ $\frac{\text { The daily sperm production per testis }}{\text { Testis weight }}$

\subsubsection{Assessment of Leydig cell counting}

The total number of Leydig cells in testis was calculated by the following formula:

Number of Leydig cells $=$

volume occupied by Leydig cell nuclei in testis volume of a single nucleus 
The volume occupied by Leydig cell nuclei was estimated by point counting method using 441 intersections coupled to a $40 \times$ objective. The volume of the nucleus of a single Leydig cell was estimated using the formula of a sphere: volume $=4 / 3 \times \pi \times r^{3}$, where $r$ corresponds to radius of Leydig cell nucleus. The diameter of the Leydig cell nucleus was estimated by ocular micrometer to $40 \times$ objective. Thirty Leydig cell nuclear diameters were measured per animal [41].

\subsection{Testosterone determination}

Blood samples were obtained from all animals studied by cardiac puncture. Heparin was used as anticoagulant. Plasma was obtained by centrifugation for 30 minutes at $3000 \mathrm{rpm}$ and stored in at $-20^{\circ} \mathrm{C}$ until used for estimating testosterone concentration using enzyme immuno assay method [42].

\subsection{Statistical analysis}

The values were presented as means and standard deviations $( \pm \mathrm{SD})$ of different groups. Differences between the mean values were estimated using one way ANOVA. The results were considered statistically significant when $\mathrm{p}<0.05$.

\section{Results}

Morphologically, by light microscopic examination, the testes of guinea pigs in the control groups (normal control, curcumin administered, and propolis administered) appeared normal. The seminiferous tubules (ST) appeared with normal interstitial spaces containing interstitial cells of Leydig. Normal germinal epithelial lining with Sertoli cells appeared with distinct nuclei and resting on intact basement membrane. Sperm bundles were seen inside the lumens of ST (Figs. 2A, B, C \& 3A, B, C).

In gentamicin treated animals, the testes showed reduction in diameters of ST and height of the germinal epithelium. The ST showed sloughing of germinal epithelium into lumen where the sperms were few. The basement membrane appeared thick, irregular and degenerated. Wide interstitial spaces with presence of few Leydig cells were observed (Figs. 2D \& 3D).

In gentamicin treated animals co-administered with curcumin, the ST appeared with normal germinal epithelium and Sertoli cells were resting on intact basement membrane and sperm bundles appeared inside the lumens. Normal interstitial spaces containing Leydig cells were seen (Figs. $2 \mathrm{E} \& 3 \mathrm{E})$.

In gentamicin treated animals co-administered with propolis, the germinal epithelium and the basement membrane appeared more or less normal with presence of sperm bundles inside the lumens. Normal interstitial spaces were seen (Figs. 2F \& 3F).

From the quantitative aspect, the weight of testis significantly decreased in gentamicin treated animals as compared to control groups $(\mathrm{p}<0.05)$. In co-administered animals with curcumin and propolis, the testes regained their normal weights and increased significantly as compared to gentamicin treated animals $(p<0.05)$. Also final body weight of the animals decreased significantly in gentamicin treated group (Table $1 \&$ Fig. 4).

The percent of volume density and absolute volume of ST decreased significantly in gentamicin treated group in comparison with control groups $(\mathrm{p}<0.05)$. Co-administration with curcumin and propolis improved these parameters significantly $(\mathrm{p}<0.05)$ and regained to control levels (Table 2 \& Figs. 5, 6).

The diameter, total length, and total surface area of ST in gentamicin treated animals were reduced and the differences were significant only in total length and total surface area as compared to control group $(\mathrm{p}<0.05)$. With co-administration of curcumin and propolis, these parameters significantly ameliorated as compared to gentamicin treated animals $(p<0.05)$ (Table $3 \&$ Figs. $7,8,9)$.

The total numbers of Sertoli cells per testis and per gram of testicular tissue decreased significantly in gentamicin treated group as compared to control groups $(\mathrm{p}<0.05)$. Co-administration of curcumin to animals treated with gentamicin significantly increased their number as compared to gentamicin treated animals $(p<0.05)$, while co-administration of propolis significantly increased their number as compared to gentamicin treated and control animals $(p<0.05)$ (Table 4 \& Fig. 10). Also, the total numbers of round spermatids per testis and per gram of testicular tissue decreased significantly as compared to control groups $(p<0.05)$. With co-administration of curcumin and propolis, the number of round spermatids was significantly ameliorated as compared to gentamicin treated group $(\mathrm{p}<0.05)$ (Table 5 \& Fig. 11).

The daily sperm production per testis and per gram of testicular tissue decreased markedly with significant differences as compared to control groups $(\mathrm{p}<0.05)$. With co-administration of curcumin and propolis, the daily sperm production improved significantly as compared to gentamicin treated group $(\mathrm{p}<0.05)$ (Table 6 \& Fig. 12).

As regards to endocrine part of the testis, the interstitial cells of Leydig, the percent of volume density and absolute volume of Leydig cell nuclei in gentamicin treated animals decreased significantly as compared to control $(p<0.05)$. With co-administration of curcumin and propolis, the values were significantly ameliorated as compared to gentamicin treated group $(\mathrm{p}<0.05)$ (Table $7 \&$ Figs. 13, 14). Also, the total numbers of Leydig cells per testis and per gram of testicular tissue decreased significantly as compared to control animals $(\mathrm{p}<0.05)$ and were significantly ameliorated $(\mathrm{p}<0.05)$ in animals co-administered with curcumin and propolis (Table $8 \&$ Fig. 15). Moreover when the blood testosterone level was assessed, it was found that the testosterone level decreased significantly in gentamicin treated animals as compared to control animals $(\mathrm{p}<0.05)$ and increased significantly when compared to gentamicin treated group $(\mathrm{p}<0.05)$ (Table 9 \& Fig. 16). 


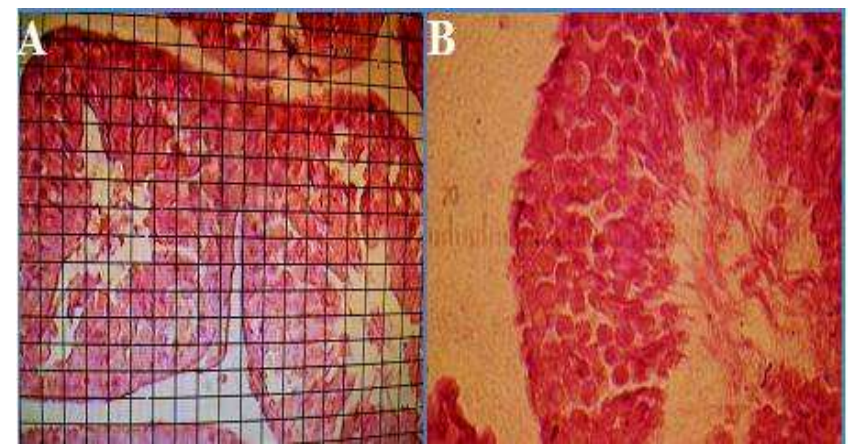

Figure 1. A. demonstration for the point counting method, B. demonstration for the ocular micrometer.

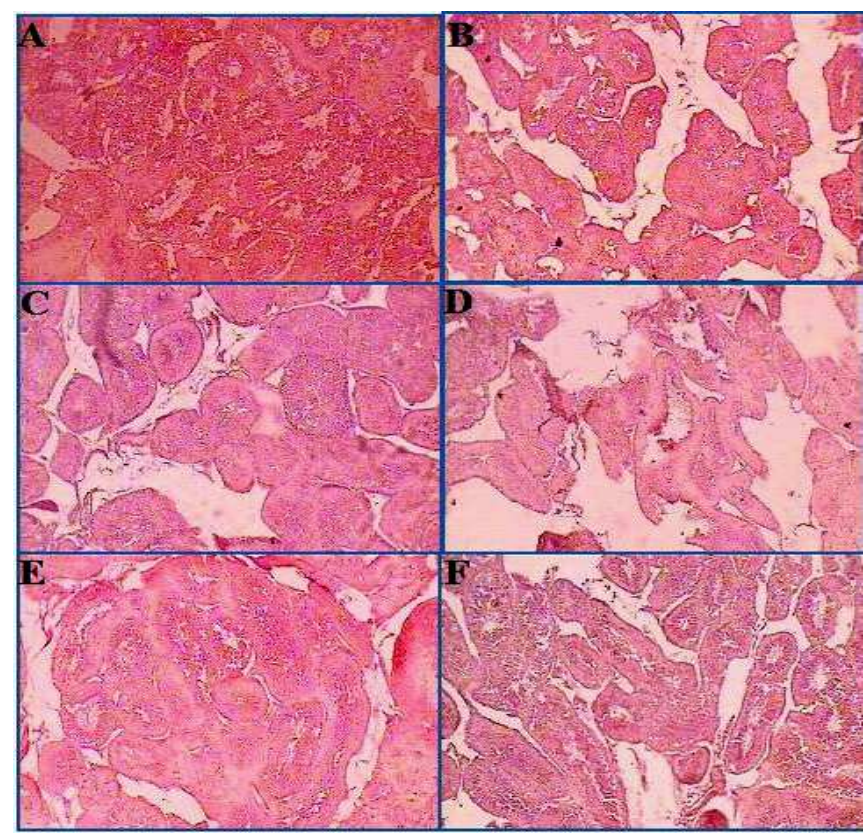

Figure 2. A photomicrograph of sections in testes of guinea pigs in different groups. A. normal control, B. positive control in curcumin administered guinea pigs, $C$. positive control in propolis administered guinea pigs, $D$. in gentamicin treated guinea pigs, E. in gentamicin treated guinea pigs co-administered with curcumin, $F$. in gentamicin treated guinea pigs co-administered with propolis. (Haematoxylin \& Eosin $\times 100$ ).

Table 1. The means and standard deviations of body and testis weight of guinea pigs in different groups

\begin{tabular}{lll}
\hline \multirow{2}{*}{ Groups } & Body weight & Testis weight \\
\cline { 2 - 3 } & Mean \pm SD & Mean \pm SD \\
\hline Control & $626 \pm 21.30$ & $2.2 \pm 0.088$ \\
Curcumin & $593 \pm 8.90^{\mathrm{a}}$ & $1.96 \pm 0.0162^{\mathrm{a}}$ \\
Propolis & $594 \pm 9.47^{\mathrm{a}}$ & $1.75 \pm 0.0267^{\mathrm{a}}$ \\
Gentamicin & $435 \pm 23.60^{\mathrm{a}}$ & $1.35 \pm 0.0123^{\mathrm{a}}$ \\
Gentamicin + Curcumin & $617 \pm 16.10^{\mathrm{b}}$ & $2.17 \pm 0.120^{\mathrm{b}}$ \\
Gentamicin + Propolis & $559 \pm 8.00^{\mathbf{a b}}$ & $2.04 \pm 0.226^{\mathbf{b}}$ \\
\hline
\end{tabular}

a: Significant differences as compared to control group $(\mathrm{P}<0.05)$

b: Significant differences as compared to gentamicin treated group $(\mathrm{P}<0.05)$

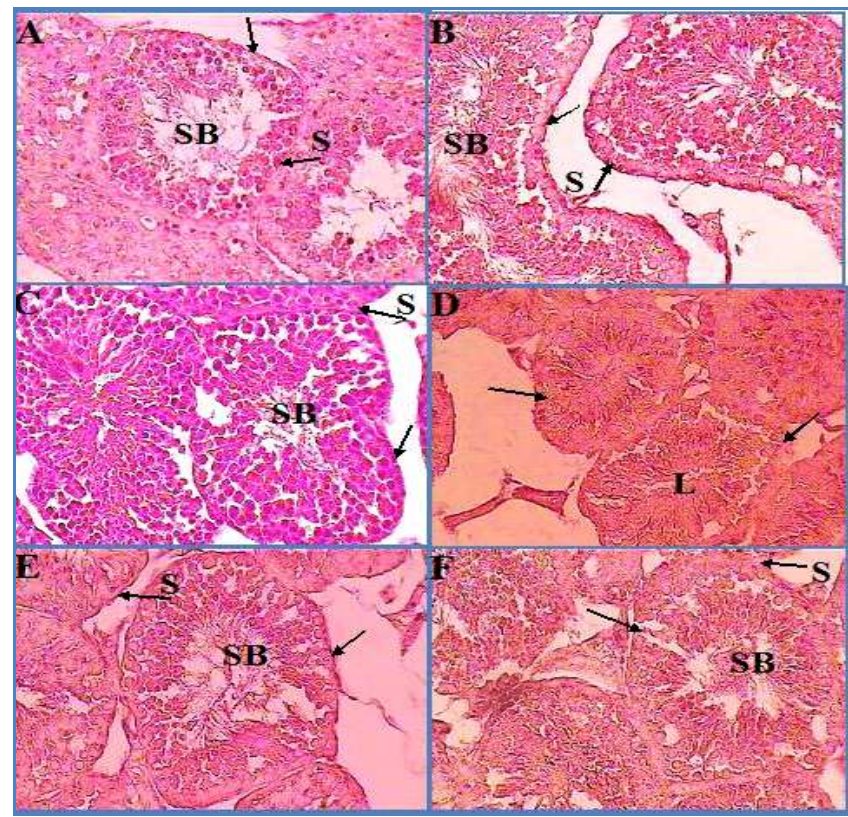

Figure 3. A photomicrograph of sections of a higher magnification in testes of guinea pigs in different groups. A. normal control, B. positive control in curcumin administered guinea pigs, C. positive control in propolis administered guinea pigs, D. in gentamicin treated guinea pigs, E. in gentamicin treated guinea pigs co-administered with curcumin, $F$. in gentamicin treated guinea pigs co-administered with propolis. Arrow= basement membrane, $S=$ Sertoli cell, L=lumen, $S B=$ sperm bundle. ( Haematoxylin \& Eosin $\times 400$ ).

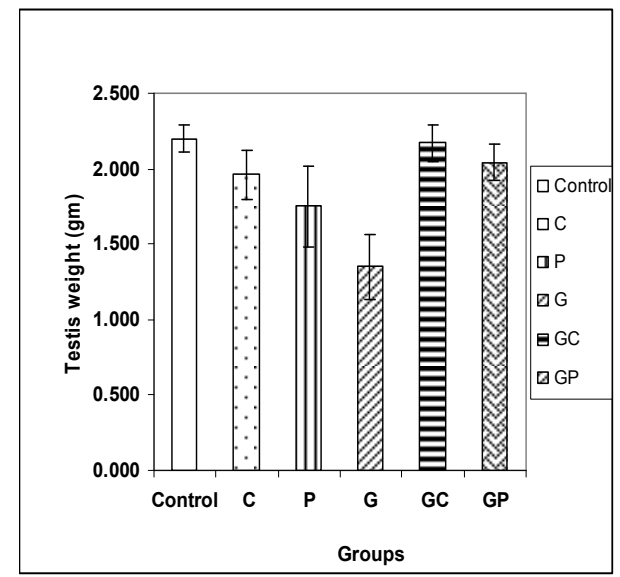

Figure 4. Testis weight in different animal groups: control, curcumin treated $(C)$, propolis treated $(p)$, gentamicin treated $(G)$, gentamicin and curcumin treated $(G C)$, gentamicin and propolis treated $(G P)$.

Table 2. The means and standard deviations of \% of volume density and absolute volume of ST in testis of guinea pig in different groups.

\begin{tabular}{lll}
\hline \multirow{2}{*}{ Groups } & $\begin{array}{l}\text { \% of volume } \\
\text { density of ST }\end{array}$ & $\begin{array}{l}\text { Absolute volume } \\
\text { of ST }\end{array}$ \\
\cline { 2 - 3 } & Mean \pm SD & Mean \pm SD \\
\hline Control & $87.42 \pm 5.14$ & $1.92 \pm 0.12$ \\
Curcumin & $85.67 \pm 5.44$ & $1.68 \pm 0.11^{\mathbf{a}}$ \\
Propolis & $94.33 \pm 2.91$ & $1.65 \pm 0.09^{\mathbf{a}}$ \\
Gentamicin & $72.38 \pm 0.76^{\mathbf{a}}$ & $0.98 \pm 0.08^{\mathbf{a}}$ \\
Gentamicin + Curcumin & $91.30 \pm 1.66^{\mathbf{b}}$ & $1.98 \pm 0.06^{b}$ \\
Gentamicin + Propolis & $94.72 \pm 2.02^{\mathbf{b}}$ & $1.93 \pm 0.08^{\mathbf{b}}$ \\
\hline
\end{tabular}

${ }^{a}$ : Significant differences as compared to control group $(\mathrm{P}<0.05)$

${ }^{\mathrm{b}}$ : Significant differences as compared to gentamicin treated group $(\mathrm{P}<0.05)$ 


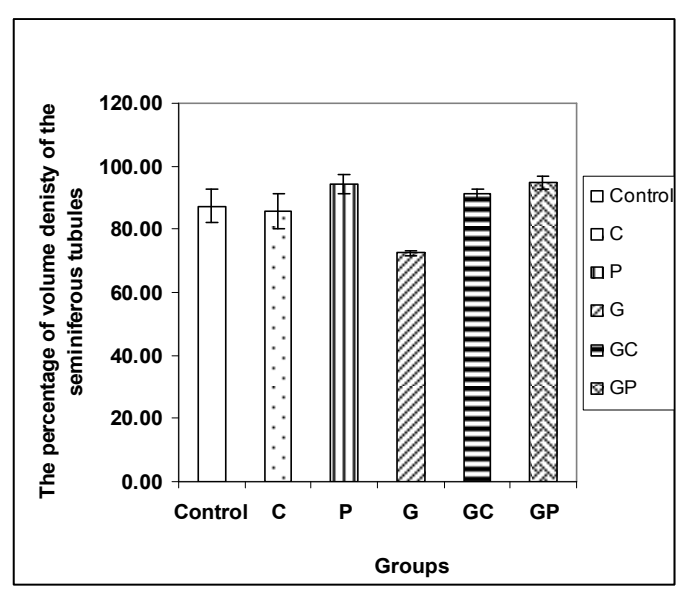

Figure 5. The percentage of volume density of seminiferous tubules in different animal groups: control, curcumin treated $(C)$, propolis treated ( $p)$, gentamicin treated $(G)$, gentamicin and curcumin treated $(G C)$, gentamicin and propolis treated $(G P)$.

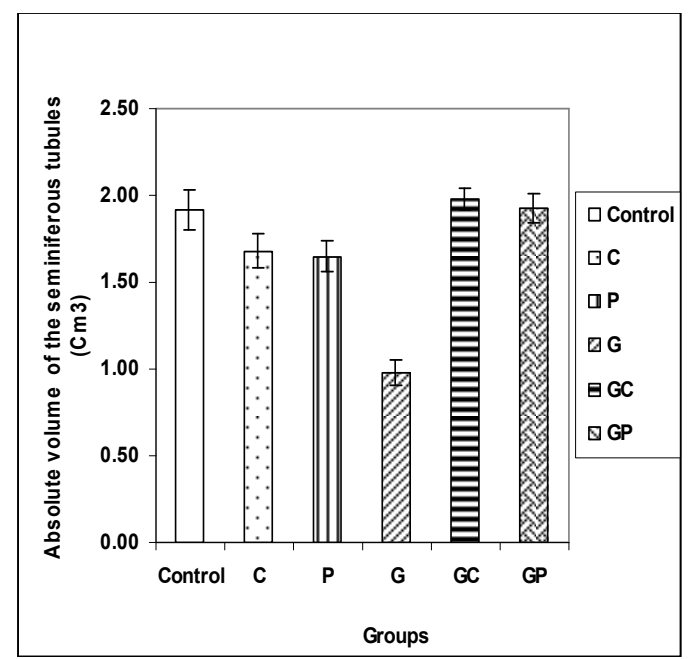

Figure 6. The absolute volume of seminiferous tubules in different animal groups: control, curcumin treated (C), propolis treated (p), gentamicin treated $(G)$, gentamicin and curcumin treated $(G C)$, gentamicin and propolis treated $(G P)$.

Table 3. The mean and standard deviation of diameter, total length and total surface area of seminiferous tubules per testis of guinea pigs in different groups.

\begin{tabular}{llll}
\hline Groups & $\begin{array}{l}\text { ST diameter } \\
(\boldsymbol{\mu m})\end{array}$ & $\begin{array}{l}\text { Total length of } \\
\text { ST }(\text { meter) }\end{array}$ & $\begin{array}{l}\text { Total surface } \\
\text { area of ST per } \\
\text { testis }(\mathbf{c m})^{\mathbf{2}}\end{array}$ \\
\cline { 2 - 4 } & Mean \pm SD & Mean \pm SD & Mean \pm SD \\
\hline Control & $115.85 \pm 9.96$ & $189.41 \pm 11.38$ & $671.36 \pm 40.35$ \\
Curcumin & $114.10 \pm 10.29$ & $166.61 \pm 9.96^{\mathbf{a}}$ & $591.72 \pm 35.39^{\mathbf{a}}$ \\
Propolis & $120.94 \pm 9.12$ & $150.34 \pm 8.25^{\mathbf{a}}$ & $554.05 \pm 30.42^{\mathbf{a}}$ \\
$\begin{array}{l}\text { Gentamicin } \\
\begin{array}{l}\text { Gentamicin } \\
+ \text { Curcumin }\end{array}\end{array}$ & $132.19 \pm 10.67^{\mathbf{b}}$ & $147.38 \pm 4.76^{\text {ab }}$ & $603.55 \pm 19.50^{a b}$ \\
$\begin{array}{l}\text { Gentamicin } \\
+ \text { Propolis }\end{array}$ & $127.43 \pm 9.02^{\mathbf{b}}$ & $154.60 \pm 6.51^{\text {ab }}$ & $610.73 \pm 25.71^{\mathbf{b}}$ \\
\hline
\end{tabular}

${ }^{\mathrm{a}}$ : Significant differences as compared to control group $(\mathrm{P}<0.05)$

${ }^{\mathrm{b}}$ : Significant differences as compared to gentamicin treated group $(\mathrm{P}<0.05)$

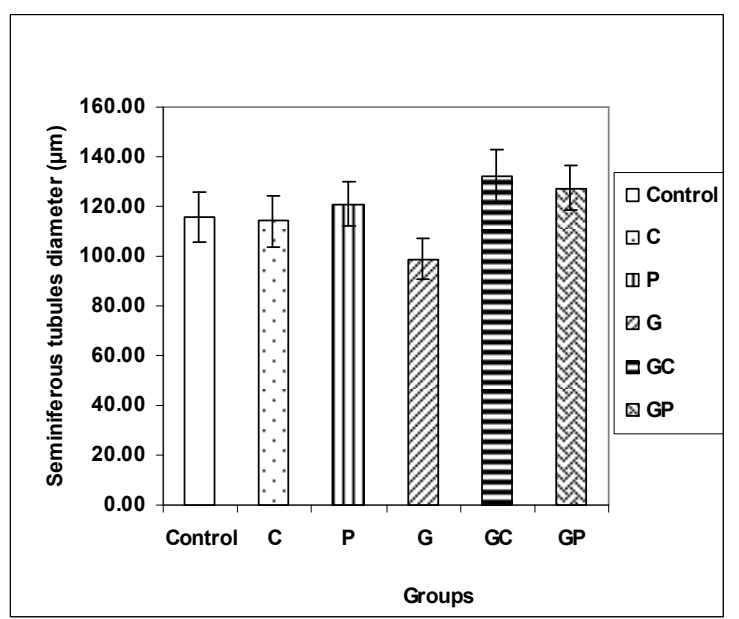

Figure 7. The diameter of seminiferous tubules in different animal groups: control, curcumin treated $(C)$, propolis treated $(p)$, gentamicin treated $(G)$, gentamicin and curcumin treated $(G C)$, gentamicin and propolis treated $(G P)$.

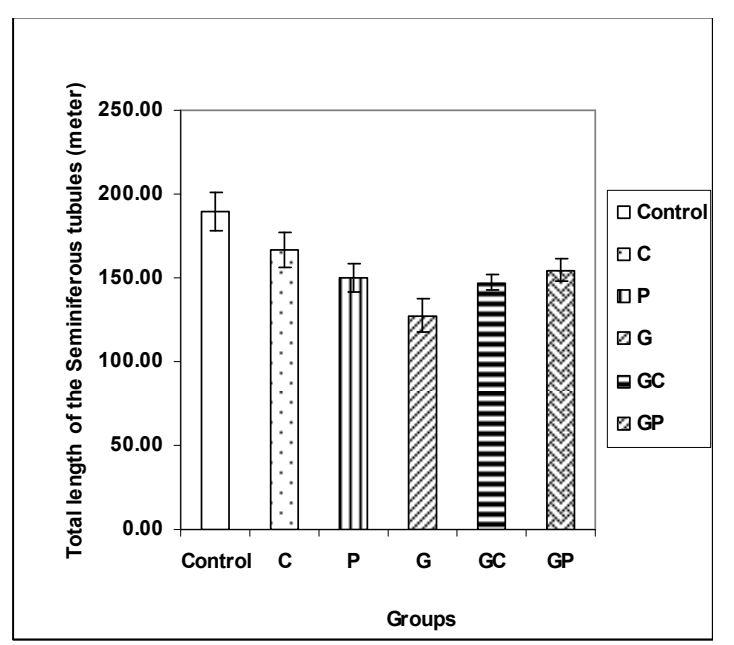

Figure 8. The total length of seminiferous tubules per testis in different animal groups: control, curcumin treated $(C)$, propolis treated $(p)$, gentamicin treated $(G)$, gentamicin and curcumin treated $(G C)$, gentamicin and propolis treated $(G P)$.

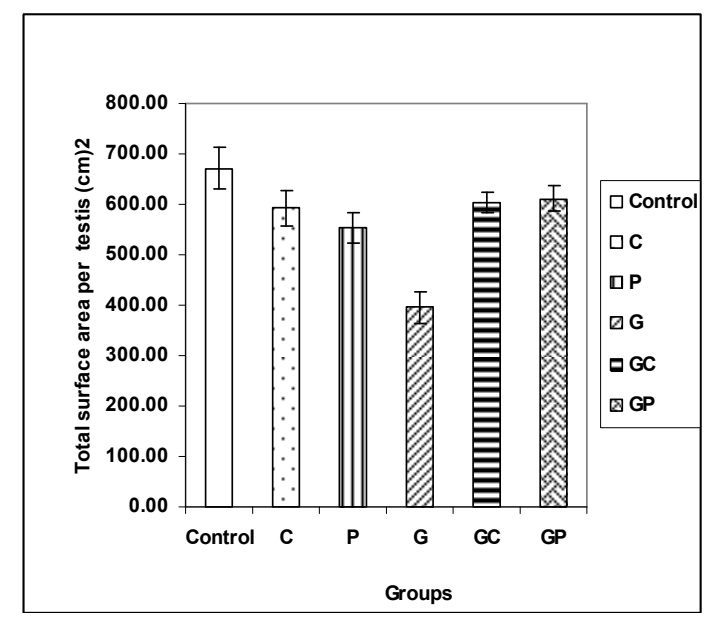

Figure 9. The total surface area of seminiferous tubules per testis in different animal groups: control, curcumin treated $(C)$, propolis treated (p), gentamicin treated $(G)$, gentamicin and curcumin treated $(G C)$, gentamicin and propolis treated $(G P)$. 
144 Fathy Ahmed Fetouh and Azab El Saied Azab: Ameliorating Effects of Curcumin and Propolis against the Reproductive Toxicity of Gentamicin in Adult Male Guinea Pigs: Quantitative Analysis and Morphological Study

Table 4. The means and standard deviations of total number of sertoli cells per testis and per gram of testicular tissue of guinea pigs in different groups.

\begin{tabular}{lll}
\hline \multirow{2}{*}{ Groups } & $\begin{array}{l}\text { n. of Sertoli cells } \\
\text { per testis } \times \mathbf{1 0}^{\mathbf{6}}\end{array}$ & $\begin{array}{l}\text { n. of Sertoli cells per gram } \\
\text { of testicular tissue } \times \mathbf{1 0}^{\mathbf{6}}\end{array}$ \\
\cline { 2 - 3 } & Mean \pm SD & Mean \pm SD \\
\hline Control & $176.78 \pm 15.20$ & $80.35 \pm 6.91$ \\
Curcumin & $228.23 \pm 20.59^{\mathbf{a}}$ & $116.44 \pm 10.50^{\mathbf{a}}$ \\
$\begin{array}{l}\text { Propolis } \\
\text { Gentamicin }\end{array}$ & $194.29 \pm 14.65^{\mathbf{a}}$ & $111.02 \pm 8.37^{\mathbf{a}}$ \\
$\begin{array}{l}\text { Gentamicin }+ \\
\text { Curcumin }\end{array}$ & $73.33 \pm 6.26^{\mathbf{a}}$ & $54.32 \pm 4.43^{\mathbf{a}}$ \\
$\begin{array}{l}\text { Gentamicin }+ \\
\text { Propolis }\end{array}$ & $219.15 \pm 15.56 \pm 14.66^{\mathbf{b}}$ & $83.69 \pm 6.75^{\mathbf{b}}$ \\
\hline
\end{tabular}

${ }^{a}$ : Significant differences as compared to control group $(\mathrm{P}<0.05)$

${ }^{\mathrm{b}}$ : Significant differences as compared to gentamicin treated group $(\mathrm{P}<0.05)$

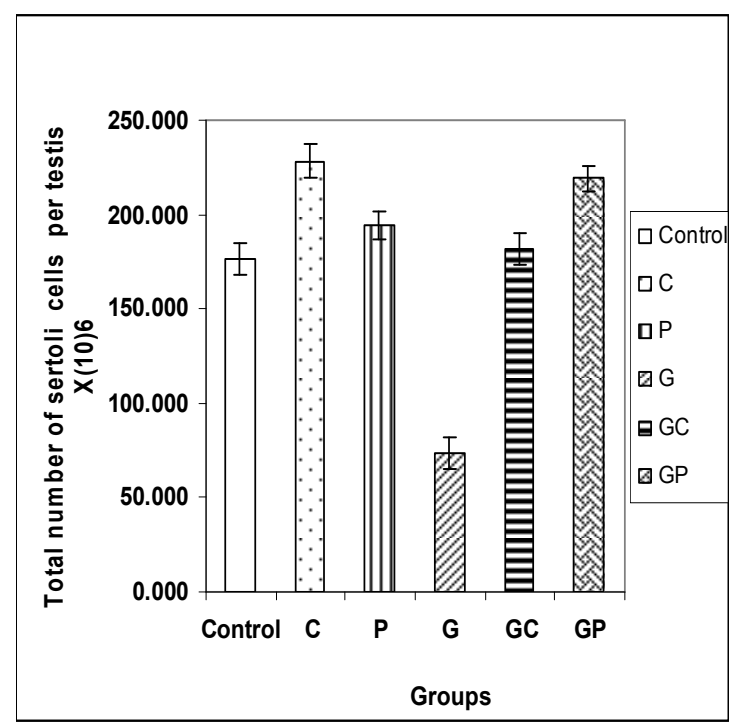

Figure 10. Total number of Sertoli cells per testis in different animal groups. control, curcumin treated $(C)$, propolis treated $(p)$, gentamicin treated $(G)$, gentamicin and curcumin treated $(G C)$, gentamicin and propolis treated $(G P)$.

Table 5. The means and standard deviations of total number of round spermatids per testis and per gram of testicular tissue of guinea pigs in different groups.

\begin{tabular}{lll}
\hline Groups & $\begin{array}{l}\text { Total } \mathbf{n} \text { of round } \\
\text { spermatids per } \\
\text { testis } \times \mathbf{1 0}^{\mathbf{6}}\end{array}$ & $\begin{array}{l}\text { Total } \mathbf{n} \text { of round spermatids } \\
\text { per gram of testicular tissue } \\
\times \mathbf{1 0}^{\mathbf{6}}\end{array}$ \\
\cline { 2 - 3 } & Mean \pm SD & Mean \pm SD \\
\hline Control & $1561.00 \pm 134.25$ & $709.93 \pm 61.05$ \\
Curcumin & $1404.00 \pm 126.64$ & $716.56 \pm 64.63$ \\
Propolis & $1217.61 \pm 91.81^{\mathbf{a}}$ & $695.78 \pm 52.46$ \\
$\begin{array}{l}\text { Gentamicin } \\
\text { Gentamicin } \\
+ \text { Curcumin }\end{array}$ & $538.42 \pm 45.93^{\mathbf{a}}$ & $398.83 \pm 34.02^{\mathbf{a}}$ \\
$\begin{array}{l}\text { Gentamicin } \\
+ \text { Propolis }\end{array}$ & $1180.76 \pm 95.29^{\text {ab }}$ & $544.13 \pm 43.91^{\text {ab }}$ \\
\hline
\end{tabular}

${ }^{\mathrm{a}}$ : Significant differences as compared to control group $(\mathrm{P}<0.05)$

${ }^{\mathrm{b}}$ : Significant differences as compared to gentamicin treated group $(\mathrm{P}<0.05)$

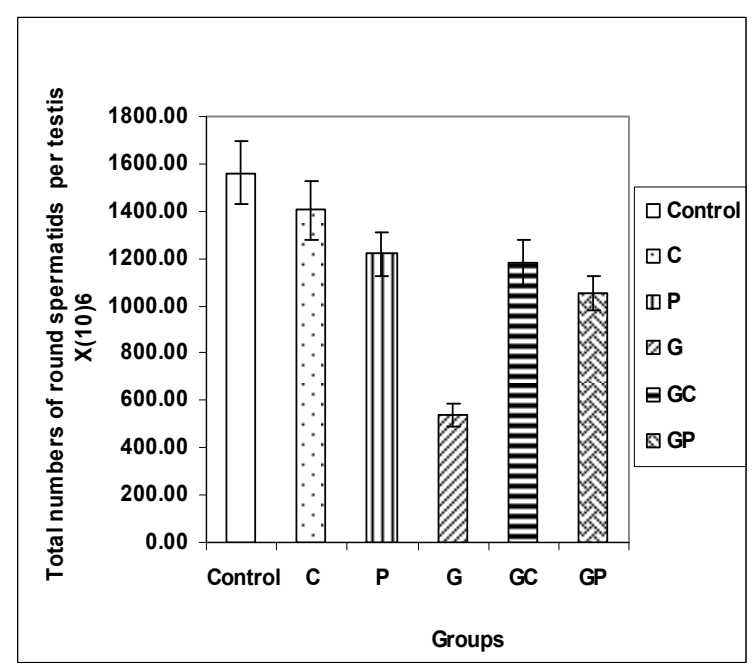

Figure 11. Total number of round spermatids per testis in different animal groups: control, curcumin treated $(C)$, propolis treated $(p)$, gentamicin treated $(G)$, gentamicin and curcumin treated $(G C)$, gentamicin and propolis treated $(G P)$.

Table 6. The means and standard deviations of daily sperm production per testis and per gram of testicular tissue of guinea pigs in different groups.

\begin{tabular}{lll}
\hline Groups & $\begin{array}{l}\text { Daily sperm } \\
\text { production per } \\
\text { testis } \times \mathbf{1 0}^{\mathbf{6}}\end{array}$ & $\begin{array}{l}\text { Daily sperm production } \\
\text { Per gram of testicular } \\
\text { tissue } \times \mathbf{1 0}^{\mathbf{6}}\end{array}$ \\
\hline Mean \pm SD & Mean \pm SD \\
\hline Control & $61.15 \pm 5.26$ & $27.80 \pm 2.39$ \\
Curcumin & $54.99 \pm 4.96$ & $28.06 \pm 2.53$ \\
Propolis & $47.67 \pm 3.59^{\mathbf{a}}$ & $27.24 \pm 2.05$ \\
Gentamicin & $21.08 \pm 1.80^{\mathbf{a}}$ & $15.62 \pm 1.33^{\mathbf{a}}$ \\
Gentamicin + & $46.23 \pm 3.73^{\text {ab }}$ & $21.31 \pm 1.72^{\text {ab }}$ \\
Curcumin & $41.27 \pm 2.92^{\text {a b }}$ & $20.23 \pm 1.43^{\text {ab }}$ \\
\hline
\end{tabular}

a: Significant differences as compared to control group $(\mathrm{P}<0.05)$.

${ }^{\mathbf{b}}$ : Significant differences as compared to gentamicin treated group $(\mathrm{P}<0.05)$.

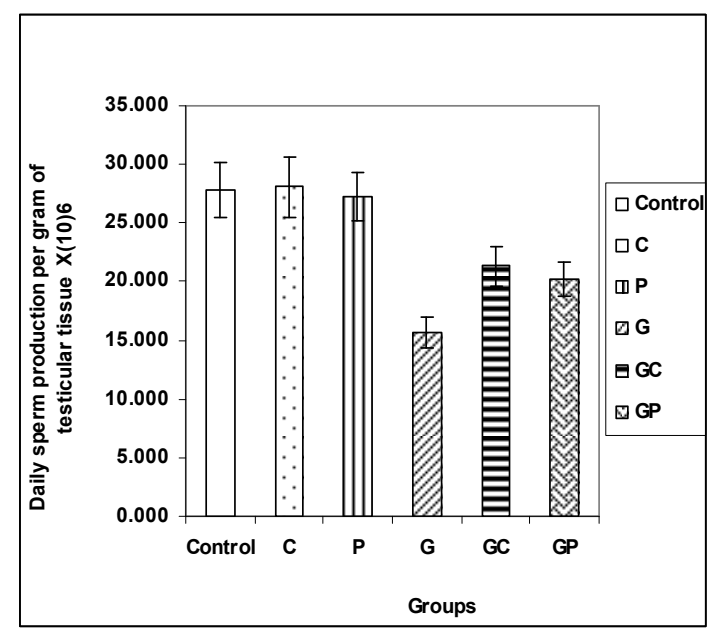

Figure 12. Daily sperm production per gram of testicular tissue in different animal groups: control, curcumin treated $(C)$, propolis treated $(p)$, gentamicin treated $(G)$, gentamicin and curcumin treated $(G C)$, gentamicin and propolis treated $(G P)$. 
Table 7. The means and standard deviations of the percentage of volume density and absolute volume of Leydig cell nuclei in testis of guinea pigs in different groups.

\begin{tabular}{lll}
\hline Groups & $\begin{array}{l}\text { \% of volume } \\
\text { density of Leydig } \\
\text { cell nuclei }\end{array}$ & $\begin{array}{l}\text { Absolute volume } \\
\text { of Leydig cell } \\
\text { nuclei }(\mathbf{c m}) 3\end{array}$ \\
\cline { 2 - 3 } Mean \pm SD & Mean \pm SD \\
\hline Control & $0.46 \pm 0.04$ & $0.010 \pm 0.0010$ \\
Curcumin & $0.36 \pm 0.03^{\mathbf{a}}$ & $0.007 \pm 0.0006^{\mathbf{a}}$ \\
Propolis & $0.36 \pm 0 . .03^{\mathbf{a}}$ & $0.006 \pm 0.0005^{\mathbf{a}}$ \\
Gentamicin & $0.26 \pm 0.02^{\mathbf{a}}$ & $0.003 \pm 0.0003^{\mathbf{a}}$ \\
Gentamicin + Curcumin & $0.43 \pm 0.03^{\mathbf{b}}$ & $0.009 \pm 0.0007^{\mathbf{b}}$ \\
Gentamicin + Propolis & $0.38 \pm 0.03^{\mathbf{a b}}$ & $0.008 \pm 0.0006^{\mathbf{a b}}$ \\
\hline
\end{tabular}

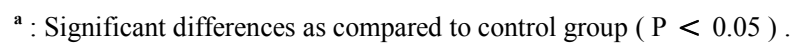

${ }^{\text {b }}$ : Significant differences as compared to gentamicin treated group $(\mathrm{P}<0.05)$

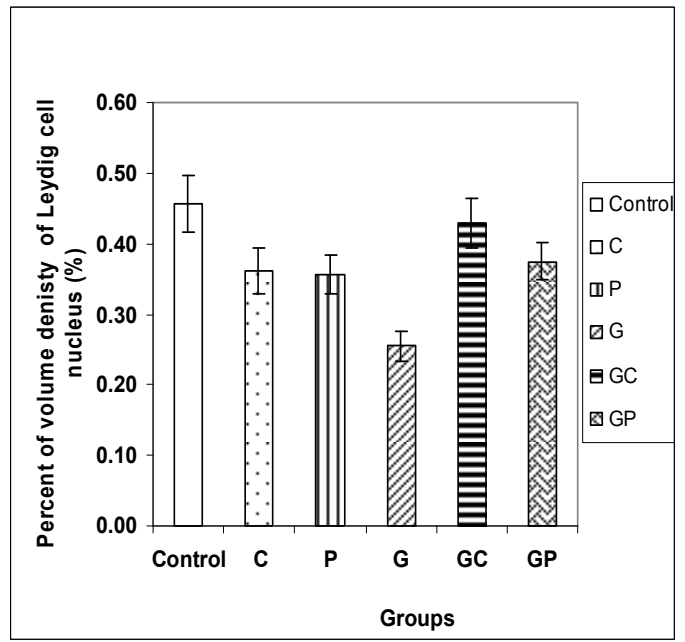

Figure 13. The percentage of volume density of Leydig cell nuclei in different animal groups: control, curcumin treated $(C)$, propolis treated $(p)$, gentamicin treated $(G)$, gentamicin and curcumin treated $(G C)$, gentamicin and propolis treated $(G P)$.

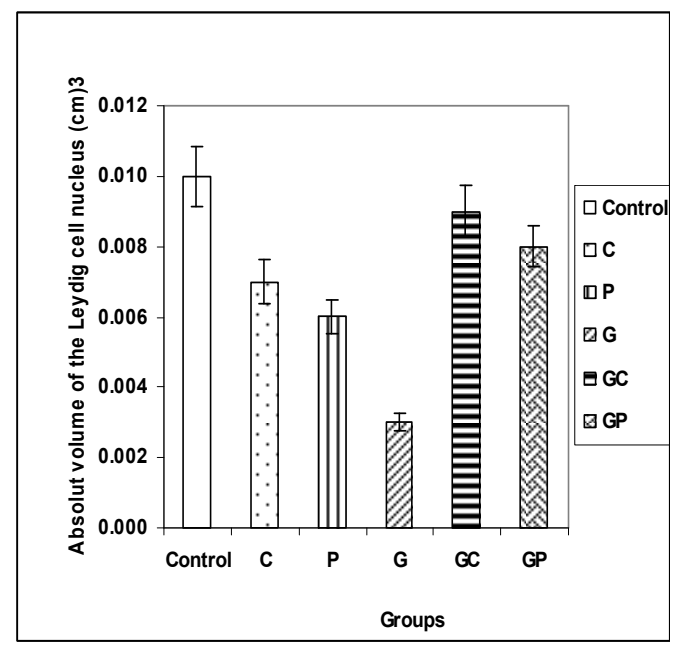

Figure 14. Absolute volume of Leydig cell nuclei in different animal groups: control, curcumin treated $(C)$, propolis treated $(p)$, gentamicin treated $(G)$, gentamicin and curcumin treated $(G C)$, gentamicin and propolis treated $(G P)$.
Table 8. The means and standard deviations of total numbers of Leydig cells per testis and per gram of testicular tissue of guinea pigs in different groups.

\begin{tabular}{|c|c|c|}
\hline \multirow[t]{2}{*}{ Groups } & $\begin{array}{l}\text { n. of Leydig cells } \\
\text { per testis } \times 10^{6}\end{array}$ & $\begin{array}{l}\text { n. of Leydig cells per gram } \\
\text { of testis } \times 10^{6}\end{array}$ \\
\hline & Mean \pm SD & Mean \pm SD \\
\hline Control & $975.00 \pm 83.85$ & $343.18 \pm 29.51$ \\
\hline Curcumin & $657.53 \pm 59.31^{\mathrm{a}}$ & $335.47 \pm 30.26$ \\
\hline Propolis & $573.46 \pm 43.24^{\mathrm{a}}$ & $327.69 \pm 24.72$ \\
\hline Gentamicin & $181.01 \pm 15.44^{\mathrm{a}}$ & $134.08 \pm 11.44^{\mathrm{a}}$ \\
\hline $\begin{array}{l}\text { Gentamicin }+ \\
\text { Curcumin }\end{array}$ & $898.07 \pm 72.47^{\mathbf{b}}$ & $413.859 \pm 33.40^{b}$ \\
\hline $\begin{array}{l}\text { Gentamicin + } \\
\text { Propolis }\end{array}$ & $636.73 \pm 45.08^{\mathbf{a b}}$ & $312.12 \pm 22.10^{b}$ \\
\hline
\end{tabular}

a : Significant differences as compared to control group ( $\mathrm{P}<0.05)$.

b : Significant differences as compared to gentamicin treated group $(\mathrm{P}<0.05)$.

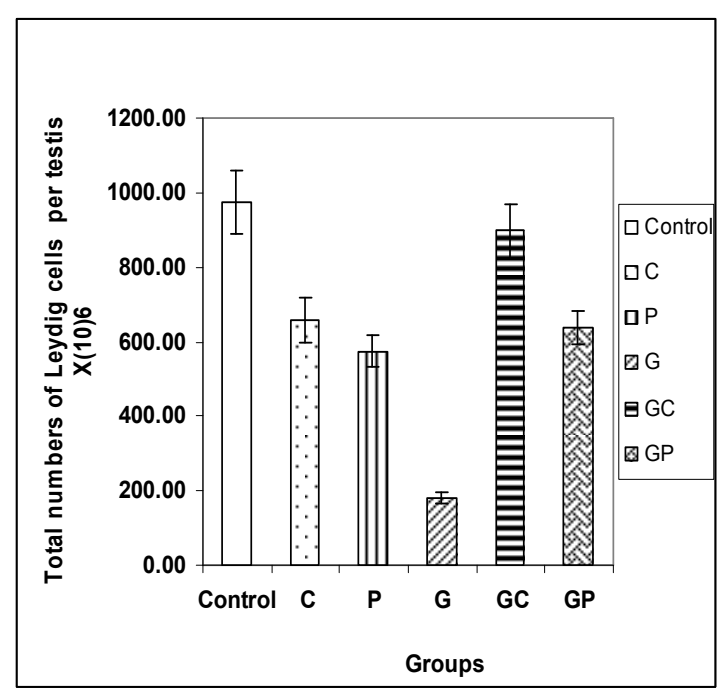

Figure 15. Total number of Leydig cell per testis in different animal groups: control, curcumin treated $(C)$, propolis treated $(p)$, gentamicin treated $(G)$, gentamicin and curcumin treated $(G C)$, gentamicin and propolis treated $(G P)$.

Table 9. The means and standard deviations of serum testosterone levels in guinea pigs in different groups

\begin{tabular}{ll}
\hline Groups & Serum testosterone levels $(\mathbf{n g} / \mathbf{m l})$ \\
\cline { 2 - 2 } & Mean \pm SD \\
\hline Control & $1.03 \pm 0.09$ \\
Curcumin & $0.92 \pm 0.08$ \\
Propolis & $0.82 \pm 0.06^{\mathbf{a}}$ \\
Gentamicin & $0.41 \pm 0.03^{\mathbf{a}}$ \\
Gentamicin + Curcumin & $1.01 \pm 0.08^{\mathrm{b}}$ \\
Gentamicin + Propolis & $1.00 \pm 0.07^{\mathbf{b}}$ \\
\hline
\end{tabular}

a: Significant differences as compared to control group $(\mathrm{P}<0.05)$.

b : Significant differences as compared to gentamicin treated group $(\mathrm{P}<0.05)$. 


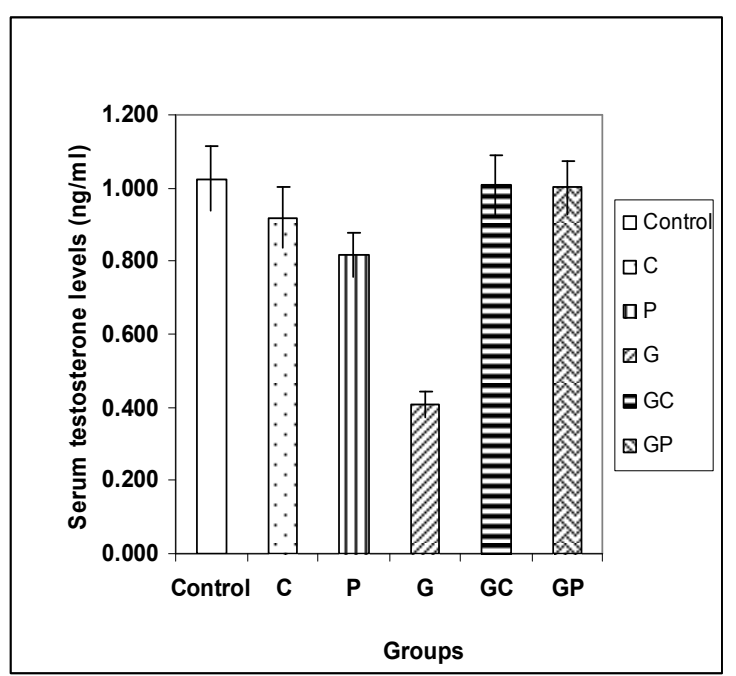

Figure 16. Serum Testosterone levels in different animal groups: control, curcumin treated $(C)$, propolis treated $(p)$, gentamicin treated $(G)$, gentamicin and curcumin treated $(G C)$, gentamicin and propolis treated $(G P)$.

\section{Discussion}

Structurally, the gentamicin had adverse effects on the testis of guinea pigs where seminiferous tubules showed sloughing of the germinal epithelium with few sperms in their lumens. The basement membrane appeared thick, irregular and degenerated. The interstitial spaces appeared wide and the Leydig cells were few. This is in agreement with previous studies, which mentioned that the gentamicin causes significant degeneration of ST with necrosis of spermatocytes, spermatids, in addition to epithelial sloughing and epithelial gaps [4, 22]. These effects may be due to the ability of gentamicin to generate destructive reactive oxygen species including superoxide, hydrogen peroxide and hydroxyl radicals and frequently used to produce oxidative and necrotic damage [43]. With co-administration of propolis and curcumin, the structural changes were ameliorated and ST regained their normal germinal epithelium and Sertoli cells with intact basement membrane and presence of sperm bundles inside their lumens. These findings are in agreement with the previous studies on propolis and curcumin as protective against other toxicants. Propolis was found to be an important antioxidant and can be effective in the protection of triphenyltin induced reproductive toxicity [44]. Curcumin was found to be useful for prevention of cadmium induced reproductive damage [45]. This may be due to the scavenging capacity of propolis to different types of reactive oxygen species, mostly free radicals as thought to be one of the main mechanisms of antioxidant action exhibited by its phenolic contents [46]. Also, the curcumin has antioxidant properties with a potent ability to inhibit reactive oxygen species formation [47]. The studies on the protective effects of propolis and curcumin against gentamicin toxicity were hardly found.

The weight of the testis in gentamicin treated animals of the present study significantly decreased. This can be explained by studies which suggested that the reduction in testicular weight reflects necrotic and regressive changes of ST $[48,49]$. Also, the decrease in the reproductive organ weights could be due to decrease in testosterone level [50]. With co-administration of propolis and curcumin, the testis weight regained to control level. This is in agreement with El Masoudy et al. [26] who found that propolis increased the relative testis weight and alleviated the negative effects of chlorpyrifos. Also, yousef et al. [44] found that the propolis significantly increases body weight and relative testis weight. Testicular weight was reported to have a high correlation with sperm reserve in the testis or epididymis and therefore a reflection of sperm production [51].

In the present study the percent of volume density and absolute volume of ST decreased significantly in gentamicin treated group and ameliorated by co-administration of propolis and curcumin. The density has a significance in that the relative mass of seminiferous tissue determines how much space is devoted to sperm production [52]. Also, in the present study the diameter, total length, and total surface area of ST in gentamicin treated animals were significantly reduced and ameliorated by co-administration of propolis and curcumin. The diameter of ST has a significance in that there is a positive relation between tubular diameter and spermatogenetic activity of testis [53]

Sertoli cells play a major role in regulation of the spermatogenesis and altering the rate of sperm production [54]. In the present study the total number of Sertoli cells in gentamicin treated animals decreased significantly. Also, the total number of round spermatids significantly decreased. This is in agreement with Narayana [4] who found that the gentamicin inhibits cell division of germ cells and protein synthesis in testis and Akondi et al. [22] who found that gentamicin treatment causes significant necrosis of spermatids and spermatocytes. The gentamicin induces these changes by increasing free radical formation and lipid peroxidation and by decreasing antioxidant enzyme levels [4]. With co-administration of propolis and curcumin, the numbers of Sertoli cells and round spermatids increased significantly as compared to gentamicin treated group. This can occur because propolis decreases the level of free radicals and lactate dehydrogenase [44] and also, the curcumin has a potent antioxidant action [47]. The reduction in Sertoli cell numbers was accompanied with a concomitant reduction of round spermatids number. This is supported by Hess and Franca [55] who found that the animals with more Sertoli cells have more germ cells per testis and the number of cells per gram of tissue combined with the number of spermatid per Sertoli cells is positively correlated with sperm production per gram of testis.

The daily sperm production per gram of testicular parynchyma is a measure for spermatogenic efficiency in sexually mature animals and used for species comparison [55]. Also, the sperm count is considered as an important parameter to assess the effects of chemicals on spermatogenesis [56]. The daily sperm production per testis and per gram of testicular tissue in gentamicin treated 
animals of the present study significantly decreased. This is in accordance with many studies which mentioned that the gentamicin can reduce sperm count, sperm motility and viability [4, 43, 57]. Free radical-induced oxidative damage to spermatozoa is one which has gained attention for its role in inducing poor sperm function and infertility [9]. Moreover, decrease in sperm concentration and total sperm output may be due to direct interaction of ROS with sperm cell membrane resulting in impairment of membrane fluidity and permeability and damage of germ cells and spermatozoa [58]. With co-administration of propolis and curcumin, the daily sperm production was significantly ameliorated as compared to control animals. This is in accordance with previous studies which mentioned that the administration of propolis caused significant improvement in sperm characteristics and male fertility of rats exposed to chlorpyrifos toxicity [26]. Also, propolis could provide protection against infertility by improving sperm production, motility, sperm count and quality in male rats exposed to aluminium chloride toxicity [59]. This may be due to the free radical scavenging activity of propolis that protects sperm membrane from the deleterious action of oxidative attacks and reduces their barbituric acid reactive substances formation [9]. Also, propolis induces a significant increase in the level of antioxidant enzymes [59]. Curcumin improved the decreased sperm count induced by cadmium in rats [60]. Co-administration of curcumin to monosodium glutamate treated rats increased the sperm count [61]. Also, Co-administration of curcumin significantly improved the daily sperm production in gallic acid induced testicular toxicity [62].

The Leydig cells are the most important component of the interstitial compartment and their main function is production of steroid hormones [63]. Testosterone is needed to initiate spermatogenesis at puberty and for maintenance of this process in adult. It is also, required for completion of meiosis and for differentiation of spermatids [64]. In the present study, the percent of volume density and total number of Leydig cells significantly decreased in gentamicin treated animals and also there was a concomitant decrease of plasma testosterone level. This is supported by Castro et al. [41] who observed that there was a significant correlation between number of Leydig cells per gram of testis to plasma testosterone level and this might occur as a consequence of increase in the population of androgen secreting cells. Also, correlation was found between the plasma testosterone level and percent volume of Leydig cells. With co-administration of propolis and curcumin to the animals, the total number of Leydig cells and plasma testosterone level increased significantly as compared to gentamicin treated animals. This is in agreement with the previous studies on propolis and curcumin. The propolis increased the level of testosterone in male rats exposed to chlorpyrifos toxicity [26], in male rabbits exposed to triphenyltin toxicity [44], in male rats exposed to aluminium chloride toxicity [59], and in male rats exposed to profenofos toxicity [65]. Also, curcumin increases the level of 17-ketosteroid reductase enzyme and subsequently increases the testosterone level in cadmium induced testicular damage [60] and in gallic acid induced testicular toxicity [62].

It can be concluded that, the gentamicin even at therapeutic dose can have adverse impacts on male reproduction. Administration of propolis or curcumin as antioxidants can ameliorate these effects. So, the patients while treated by gentamicin should be advised to use one of them.

\section{References}

[1] Carlsen E, Giwercman A, Keiding N and Skakkebaek NE: Evidence for decreasing quality of semen during past 50 years. BMJ 1992;305(6854):609-13

[2] Sikka SC and Wang R: Endocrine disruptors and estrogenic effects on male reproductive axis. Asian J Androl 2008;10:134-45

[3] Haidel G, Schuppe HC, Köhn FM and Leiber C: Evidence-based drug therapy for male infertility. Urologe A 2008;47(12):1555-6

[4] Narayana K: An aminoglycoside antibiotic gentamicin induces oxidative stress, reduces antioxidants reserve and impairs spermatogenesis in rats. J Toxicol Sci 2008;33(1):85-96

[5] Mattew TH: Drug-induced renal disease. Med J Aust 1992;156: 724-728

[6] Ali BH: Agents ameliorating or augmenting experimental gentamicin nephrotoxicity. Some recent research. Food Chem Toxicol 2003;41: 1447-1452

[7] Khaki A, Heidari M, Ghaffari Novin $M$ and Khak AA: Adverse effects of ciprofloxacin on testis apoptosis and sperm parameters in rats. Iran J Reprod Med 2008;6(2):14-20

[8] Mosher WD and Pratt WF: Fecundity and infertility in the United States: Incidence and trends. Fertil Steril 1991;56(2):192-193

[9] Russo A, Troncoso N, Sanchez F, Garbarino JA and Vanella A: Propolis protects human spermatozoa from DNA damage caused by benzo[a]pyrene and exogenous reactive oxygen species. Lif Sci 2006;78:1401-1406

[10] Heeba GH, and Abd-Elghany MI: Effect of combined administration of ginger (Zingiber Officinale Roscoe) and atorvastatin on the liver of rats. Phytomedicine 2010;17(14): 1076-81

[11] Ho C, Ferrara T, Chen Q, Rosen R and Huang M: Phytochemicals in teas and rosemary and their cancer preventive properties in: Food phytochemicals for cancer prevention. American Chemical Society, Washington, DC, 1994, pp.2-19

[12] Joe B, Vijaykumar M and Lokesh BR: Biological properties of curcumin-cellular and molecular mechanisms of action. Crit Rev Food Sci Nutr 2004;44: 97-111

[13] Venkatesan N, Punithavathi D and Arumugam V: Curcumin prevents adriamycin nephrotoxicity in rats. Br J Pharmacol 2000;129(2): 231-234 
[14] Tirkey N, Kaur G, Vij G and Chopra K: Curcumin a diferuloylmethane, attenuates cyclosporine induced renal dysfunction and oxidative stress in rat kidneys. J Biosc 2005; 22(2): $233-46$

[15] Ruby AJ, Kuttan G, Babu KD and Kuttan R: Anti-tumor and anti-oxidant activity of natural curcuminoids. Cancer Lett 2005;94: 79-83

[16] Marquele FD, Di Mambro VM, Georgetti SR, Casagrande R, Valim YML and Fonseca MJV: Assessment of the antioxidant activities of Brazilian extracts of propolis alone and in topical pharmaceutical formulation. J Pharmacol Biomed Anal 2005;39: 455-462

[17] Li YJ, Lin JL, Yang CW and Yu CC: Acute renal failure induced by a Brazilian variety of propolis. Am J Kid Dis 2005;46(6): e125-9

[18] Gunduz C, Biray C, Kosova B, Yilmaz B, Eroglu Z, Sahin F, Omay SB and Cogulu O: Evaluation of Manisa propolis effect on leukemia cell line by telomerase activity. Leuk Res 2005;29(11): 1343-6

[19] Ozguner F, Bardak Y and Comlekci S: Protective effects of melatonin and caffeic acid phenethyl ester against retinal oxidative stress in long-term use of mobile phone. a comparative study. Mol Cell Biochem 2006;282(1-2): 83-88

[20] Nouri M, Khaki A, Fathiazad F and Rashidi MR: The protective effects of carrot seeds extracts on spermatogenesis and cauda epididymal sperm reserves in gentamicin treated rats. Yakhteh Med J 2009;11:327-33

[21] Elias A and Nelsen B: Subchronic evaluation of ciprofloxacin and perfloxacin on sperm parameters of male guinea pigs. Asian J Exp Biol Sci 2012;3(3):595-601

[22] Akondi RB, Akula A and Challa SR: Protective effects of rutin and naringin on gentamicin induced testicular oxidative stress. Eu J Gen Med 2011;8(1):57-64

[23] El-Khayat Z, Ezzat AR, Arbid MS and Rasheed WI, Elias TR Potential effects of bee honey and propolis against the toxicity of ochratoxin a in rats. Macedonian J Med Scie 2009;2(4): $1-8$

[24] Reddy MVB, Sasikala P, Karthik A, Sudheer SD and Murthy LN: Protective role of curcumin against arsenic trioxide toxicity during gestation and lactational periods. Global Veterinaria 2012;9(3):270-276

[25] Devi KR and Raju MM: Protective in vivo effects of curcumin on chromium induced genotoxicity in germ cells of mice. International Journal of Pharma And Bio Sciences 2012;3(1):243-250

[26] El Mazoudy RH, Attia AA and El-Shenawy NS: Protective role of propolis against reproductive toxicity of chlorpyrifos in male rats. Pestic Biochem Physiol 2011;101:175-181

[27] Mahmoud ME and Elsoadaa SS: Protective effect of ascrobic aid, bipropolis and royal jelly against aluminum toxicity in rats. Journal of Natural Sciences Research 2013;3(1):102-112

[28] Amann RP and lambiase JT: The male rabbit III. Determination of daily sperm production by means of testicular homogenates. J Anim Sci 1969; 28:369-374.

[29] Blanco A, Moyano R, Vivo J, Flores-Acuna R, Molina A,
Blanco C, Agüera E and Monterde JG: Quantitative changes in the testicular structure in mice exposed to low doses of cadmium. Environ Toxicol and pharmacol 2007; 23:96-101.

[30] Mori $\mathrm{H}$ and Christensen AK: Morphometric analysis of Leydig cells in the normal rat testis. J Cell Biol 1980; $84: 340-354$

[31] Ewing LL, Zirkin BR, Cohran RC, Kromann N, Peters C and Ruiz-Bravo N: Testosterone secretion by rat, rabbit, guinea pig, dog, and hamster testes perfused in vitro: correlation with Leyidg cell mass. Endocrinol 1979;105:1135-1142

[32] Wing $\mathrm{T}$ and Christensen K: Morphometric studies on rat seminiferous tubules. Amer J Anat 1982; 168: 13-25.

[33] Sprando RL, Collins TFX, Wiesenfeld P, Babu US, Rees C, Black T, Olejnik N and Rorie J: Testing the potential of flaxseed to affect spermatogenesis: Morphometry. Food and Chemical Toxicol 2000; 38:887-892.

[34] Bielli A, Gastel MT, Pedrana G, Morana A, Castrillejo A, Lundeheim N, Forsberg $M$ and Rodriguez-Martinez H: Influence of pre and post pubertal grazing regimes on adult testicular morphology in extensively reared corriedale rams. Anim Reprod Sci 2000; 58:73-86.

[35] Berndtson WE: Methods for quantifying mammalian spermatogenesis: A review. J Anim Sci 1977; 44(5): 818-833.

[36] Abercrombie M: Estimation of nuclear population from microtome sections. Anat Rec 1946; 94:239-247

[37] de Barros JB, de Paula TA, da Matta SL, Fonseca CC, Leite FL, Rossi Jr JL, de Oliveira PC and da Costa EP: Sertoli cell index and spermatic reserves in adult captive African lions (Panthera Leo, Linnaeus, 1758). Anim Repord Sci; 2007;102(3-4):350-356 doi: 10.1016/j. anireprosci. 2007.04 .002

[38] Johnson L, Varner DD, Roberts ME, Smith TL, Keillor GE and Scrutchfield WL: Efficiency of spermatogenesis: a comparative approach. Anim Repord Sci 2000; 60:471-480.

[39] Noller DW, Flickinger CJ and Howards SS: Duration of the cycle of the seminiferous epithelium in the guinea pig determined by tritiated thymidine autoradiography. Biol Reprod 1977; 17:532-534

[40] Clermont Y and Harvey SC: Duration of the cycle of the seminiferous epithelium of normal, hypophysectomized and hypophysectomized-hormone treated albino rats. Endocrinol $1965 ; 76: 80-89$.

[41] Castro ACS, Berndtson WE and Cardoso FM: Plasma and testicular testosterone levels, volume density and number of Leydig cells and spermatogenesis efficiency of rabbit. Brazilian Journal of Medical and Biological Research 2002;35:493-498

[42] Amballi AA, Dada OA, Adeleye AO and Jide S: Evaluation of the determination of reference ranges for reproductive hormones (prolactin, FSH, LH and testosterone) using enzyme immuno assay method. Sci Res Essay $2007 ; 2: 135-137$

[43] Khaki A, Ghaffari NM, Khaki AA, Fathiazad F, Khabiri M and Hossinchi J: Ultrustructural study of gentamicin and ofloxacin effect on testis tissue in rats: light and transmission electron microscopy. AJPP 2009C; 3(4):105-9 
[44] Yousef MI, Kamel KI, Hassan MS and El-Morsy AMA: Protective role of propolis against reproductive toxicity of triphenyltin in male rabbits. Food Chem Toxicol 2010; 48(7):1846-1852

[45] Oguzturk H, Ciftci O, Aydin M, Timurkaan N, Beytur A and Yilmaz F: Ameliorative effects of curcumin against cadmium toxicity on male reproductive system in rats. Andrologia 2012, 44:243-249

[46] Pham-Huy L, He H, and Pham-Huy C: Free radicals, antioxidants in disease and health. Int $\mathrm{J}$ Biomed Sci 2008;4:89-96

[47] Biswas SK, McClure D, Jimenez LA, Megson IL and Rahman I: Curcumin induces glutathione biosynthesis and inhibit NF-kappa B activation and interleukin-8 release in alveolar epithelial cells. Mechanism of free radical scavenging activity. Anti Red Sign 2005;7: 32-41

[48] Joshi SC, Mathur R and Gulati N: Testicular toxicity of chlorpyrifos (an organophosphate pesticide) in albino rat. Toxicol Ind Health 2007;23:439-444

[49] Udoh P and Kehinde A: Studies on antifertility effect of pawpaw seeds (Carica papaya) on the gonads of male albino rats. Phytother Res 1999;13(3):226-2228

[50] El-Ashmawy IM, Saleh A and Salama OM: Effects of marjoram volatile oil and grape seed extract on ethanol toxicity in male rats. Basic \& Clinical Pharmacology \& Toxicology 2007;101:320-327

[51] Adeyemo GO, Longe OG and Adejumo DO: The reproductive performance of breeder cocks fed cottonseed cake-based diets. International Journal of Poultry Science 2007;6(2):140-144

[52] Franca LR, Avelar GF, and Almeida FF: Spermatogenesis and sperm transit through the epididymis in mammals with emphasis on pigs. Theriogenology 2005;63(2):300-318

[53] Franca LR and Russell LD: The testis of domestic animals in: Male reproduction. A multidisciplinary overview, Regadera J, Martinez-Garcia, Eds, Churchill living stone, Madrid, 1998, p. $197-219$

[54] Russell LD: Morphological and functional evidence for Sertoli-germ cell relationship. In: Russell LD, Griswold MD (eds.), The Sertoli cell. Clearwater Fl: Cache River Press; 1993 , P. $365-390$
[55] Hess RA and de Franca LR: Molecular mechanisms in spermatogenesis. Chapter I: spermatogenesis and cycle of the seminiferous epithelium, edited by C.Yan Cheng, Landes. Bioscience and Springer Science 2008

[56] Yousef MI: Protective role of ascorbic acid to enhance reproductive performance of male rabbits treated with stannous chloride. Toxicol 2005;207:81-89

[57] Zahedi A and Khaki A: Recovery effect of zingiber officinale on testis tissue after treatment with gentamicin in rats. Journal of Medicinal Plant Research 2014;8(6):288-291

[58] Sarkar M, Chaudhuri GR, Chattopadhyay A and Biswas NM: Effect of sodium arsenite on spermatogenesis, plasma gonadotrophins and testosterone in rats. Asian J Androl 2003; 5: $27-31$

[59] Yousef MI and Salama AF: Propolis protection from reproduction toxicity caused by aluminium chloride in male rats. Food Chem Toxicol 2009;47:1168-1175

[60] Salama AF and El-Bahr SM: Effect of curcumin on cadmium-induced oxidative testicular damage in rats. JMRI 2007;28(2):167-73

[61] Sakr SA and Badawy GM: Protective effect of curcumin on monosodium glutamate-induced reproductive toxicity in male rats. Global Journal of Pharmacology 2013;7(4):416-422

[62] Abarikwu SO, Akiri OF, Durojaiye MA and Alabi AF: Combined administration of curcumin and gallic acid inhibits gallic acid-induced suppression of steroidogenesis, sperm output, antioxidant defenses and inflammatory responsive genes. J Steroid Biochem Mol Biol. 2014;143C:49-60. doi:10.1016/j.jsbmb. 2014.02.008

[63] Kim I and Yang H: Morphometric study of the testicular interstitium of rats during postnatal development. The Korean J Anat 1999;32:849-858

[64] Poccia D: Intercellular signaling systems. In: Poccia D (Editor), Molecular aspects of spermatogenesis. R.G. Landes company, Austin, TX, USA, 1994

[65] Abu-Aita NA, Hashesh MA and Mohamed AH: Clinicopathological and cytogenetic studies on the ameliorative effect of propolis against profenofos toxicity in rats. Global Veterinaria 2012; 9(6):669-682. 